ARTICLE

Received 30 Sep 2014 | Accepted 20 Feb 2015 | Published 23 Mar $2015 \quad$ DOl: 10.1038/ncomms7700

\title{
Efficient hole-blocking layer-free planar halide perovskite thin-film solar cells
}

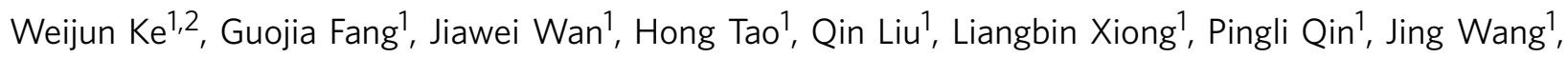
Hongwei Lei ${ }^{1}$, Guang Yang ${ }^{1}$, Minchao Qin ${ }^{1}$, Xingzhong Zhao ${ }^{1} \&$ Yanfa Yan ${ }^{2}$

Efficient lead halide perovskite solar cells use hole-blocking layers to help collection of photogenerated electrons and to achieve high open-circuit voltages. Here, we report the realization of efficient perovskite solar cells grown directly on fluorine-doped tin oxide-coated substrates without using any hole-blocking layers. With ultraviolet-ozone treatment of the substrates, a planar $\mathrm{Au} /$ hole-transporting material/ $\mathrm{CH}_{3} \mathrm{NH}_{3} \mathrm{Pbl}_{3-x} \mathrm{Cl}_{x} /$ substrate cell processed by a solution method has achieved a power conversion efficiency of over $14 \%$ and an open-circuit voltage of $1.06 \mathrm{~V}$ measured under reverse voltage scan. The open-circuit voltage is as high as that of our best reference cell with a $\mathrm{TiO}_{2}$ hole-blocking layer. Besides ultraviolet-ozone treatment, we find that involving $\mathrm{Cl}$ in the synthesis is another key for realizing high open-circuit voltage perovskite solar cells without hole-blocking layers. Our results suggest that $\mathrm{TiO}_{2}$ may not be the ultimate interfacial material for achieving high-performance perovskite solar cells.

\footnotetext{
${ }^{1}$ Key Laboratory of Artificial Micro- and Nano-structures of Ministry of Education of China, Department of Electronic Science and Technology, School of Physics and Technology, Wuhan University, Wuhan 430072, China. ${ }^{2}$ Department of Physics and Astronomy, The University of Toledo, Toledo, Ohio 43606, USA. Correspondence and requests for materials should be addressed to G.F. (email: gjfang@whu.edu.cn) or to Y.Y. (email: yanfa.yan@utoledo.edu).
} 
O rganic-inorganic lead halide perovskite solar cells have attracted much attention in recent years. The power conversion efficiency (PCE) of lead halide perovskitebased solar cells has rapidly increased from 3.8 to $\sim 20.1 \%$ (certified) in just 5 years ${ }^{1-8}$. Lead halide perovskite solar cells use either the mesoscopic or the planar cell architecture. Regardless of the cell architecture, high-efficiency lead halide perovskite solar cells exclusively use hole-blocking layers (HBLs)/electrontransporting layers (ETLs) and hole-transporting layers (HTLs)/ electron-blocking layers (EBLs). These intrinsic interfacial layers are believed critically necessary for achieving high open-circuit voltages ( $V_{\mathrm{OC}}$ 's) and efficiencies because they promote effective carrier separations and charge recombination reduction at the front contacts, typically transparent conducting oxides such as fluorine-doped tin oxide (FTO) or indium-doped tin oxidecoated glass, and back contacts, typically metals such as Ag or Au. In the inverted structures, efficient perovskite solar cells have been achieved using organic HBLs and EBLs ${ }^{9}$. In the regular structures, the most used HBL/ETL and HTL/EBL materials reported in literature are $\mathrm{TiO}_{2}$ and $2,2^{\prime}, 7,7^{\prime}$-tetrakis- $(N, N$-di-pmethoxyphenylamine)-9, $9^{\prime}$-spirobifluorene (spiro-OMeTAD), respectively. A report has also shown that $\mathrm{Y}$ doping of $\mathrm{TiO}_{2}$ ETL can improve the cell performance ${ }^{6}$. The reason why spiroOMeTAD is a good HTL material for achieving high-efficiency cells has been investigated ${ }^{10}$. Recently, perovskite solar cells using poly(triaryl amine) HTLs have achieved the highest certified efficiency ${ }^{7}$. Significant efforts have been paid to search for alternative HBL and HTL materials or even to eliminate HTL layer ${ }^{1-14}$. Some lead halide perovskite solar cells without HTLs have achieved reasonable conversion efficiencies. It has been shown that the remnant $\mathrm{PbI}_{2}$ layer in a $\mathrm{CH}_{3} \mathrm{NH}_{3} \mathrm{PbI}_{3}$ film prepared by a two-step method can act as a $\mathrm{HBL}^{15}$. There are many oxides, for example, $\mathrm{ZnO}, \mathrm{In}_{2} \mathrm{O}_{3}$ and $\mathrm{SnO}_{2}$, that exhibit similar or even better electronic and optical properties than $\mathrm{TiO}_{2}$. Theoretically, these oxides should be as good HBL materials as $\mathrm{TiO}_{2}$. For example, perovskite solar cells using $\mathrm{ZnO}$ as HBL have achieved PCEs as high as $15.7 \%$. To further understand the operation mechanism of lead halide perovskite solar cells and to further improve the cell performance, it is important to understand whether or not $\mathrm{TiO}_{2}$ is the ultimate $\mathrm{HBL}$ for achieving high-efficiency cells in the regular structure.

In this paper, we report on the realization of efficient planar lead halide perovskite solar cells grown directly on FTO substrates without any HBLs. By applying ultraviolet-ozone (UVO) treatment to the FTO substrates, a simple planar $\mathrm{Au} /$ spiro-OMeTAD/ $\mathrm{CH}_{3} \mathrm{NH}_{3} \mathrm{PbI}_{3-x} \mathrm{Cl}_{x} / \mathrm{FTO}$ cell processed by a

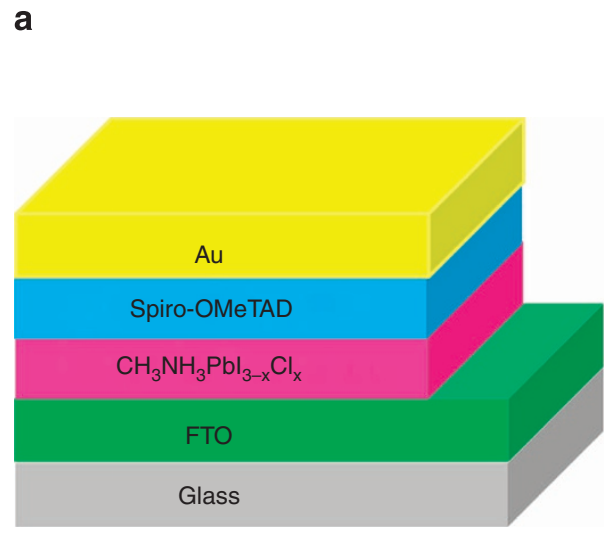

low-temperature solution method has achieved a PCE of over $14 \%$ and a $V_{\mathrm{OC}}$ of $1.06 \mathrm{~V}$ measured under the reverse voltage scan with a scan rate of $0.1 \mathrm{~V} \mathrm{~s}^{-1}$. The $V_{\mathrm{OC}}$ is as high as our best reference device using $\mathrm{a} \mathrm{TiO}_{2} \mathrm{HBL}\left(\mathrm{PCE}=16.07 \%, V_{\mathrm{OC}}=1.06 \mathrm{~V}\right)$ measured with the same voltage scan and rate. The perovskite absorbers were deposited by the one-step process and there are no obvious unreacted $\mathrm{PbI}_{2}$ layers at $\mathrm{FTO}$ /perovskite interfaces to act as HBLs. Our results, therefore, strongly suggest that $\mathrm{TiO}_{2}$ may not be an ultimate HBL material for achieving high-efficiency lead halide perovskite solar cells. We show that involving $\mathrm{Cl}$ in the synthesis process and applying UVO treatment to the FTO substrates are two key factors for achieving high $V_{\text {OC }}$ lead halide perovskite solar cells without any HBLs. The UVO treatment improves the perovskite film coverage, and, therefore, the fill factor (FF) and the $V_{\mathrm{OC}}$. $\mathrm{Cl}$ may segregate to and passivate $\mathrm{FTO} /$ $\mathrm{CH}_{3} \mathrm{NH}_{3} \mathrm{PbI}_{3-x} \mathrm{Cl}_{x}$ interfaces and, thus, improves the $V_{\mathrm{OC}}$. Our results reveal that alternative HBL materials or cell structures should be explored to further improve the performance of lead halide perovskite solar cells.

\section{Results}

Device structure. Figure 1a shows the device structure of our perovskite solar cells grown directly on FTO substrates without any HBLs. The perovskite films were directly coated on FTO substrates by a one-step spin-coating method. Following the deposition of the perovskite layer, a spiro-OMeTAD HTL $(\sim 250 \mathrm{~nm})$ was deposited by spin coating. The cells were finished with thermally evaporated Au back contacts. The FTO substrates have a sheet resistance of $14 \mathrm{Ohms}$ per square. Therefore, the FTO layers are the $\mathrm{n}^{+}$electrodes. Reports in literature have shown that some lead halide perovskite solar cells behave as $\mathrm{p}-\mathrm{i}-\mathrm{n}$ cells ${ }^{3,16-18}$. Our lead halide perovskites thin films are highly resistive and have low carrier concentrations, typically below the sensitivity of our Hall measurement system $\left(\sim 10^{14} \mathrm{~cm}^{-3}\right)$. Therefore, the operation mechanism for our cells may be similar to that of a p-i-n cell. Figure $1 b$ shows the possible transportation of the photogenerated carriers and the energy band diagram of cells. The Au back contact makes good Ohmic contact to the p-type spiro-OMeTAD HTL (Supplementary Fig. 1).

Because halide perovskite-based solar cells typically use very thin absorber layers $(300-500 \mathrm{~nm})$, it is critical to form perovskite thin films with full coverages and smooth surfaces. This is particularly important for the planar cell architecture because an incomplete coverage of a perovskite film results in low-resistance shunting paths and low light absorption in the solar cell.

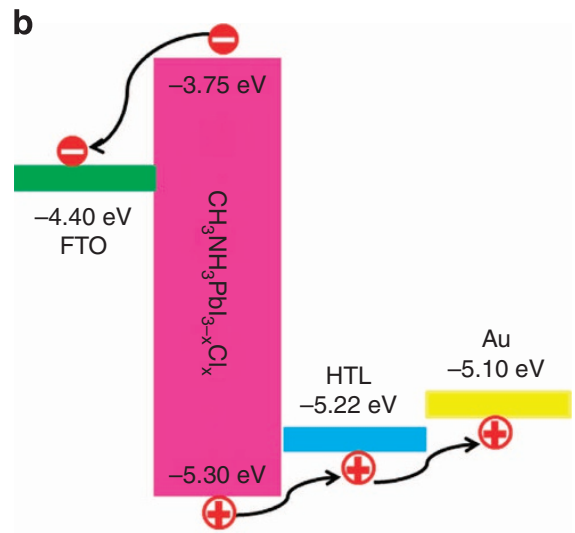

Figure 1 | Device architecture and energy diagram. (a) Schematic view of the perovskite solar cell configuration: Glass substrate, FTO front contact, $\mathrm{CH}_{3} \mathrm{NH}_{3} \mathrm{Pbl}_{3-x} \mathrm{Cl}_{x}$ film, spiro-OMeTAD HTL and Au back contact. (b) Energy band diagram of the FTO/ $\mathrm{CH}_{3} \mathrm{NH}_{3} \mathrm{Pbl}{ }_{3-x} \mathrm{Cl}_{x} /$ spiro-OMeTAD HTL/Au solar cell showing the separation and collection of photogenerated carriers. 
Significant efforts have been developed to improve film coverage and crystalline quality ${ }^{19-21}$. We found that the residual organic species or surface-OH basis group absorbed on the FTO substrates have detrimental effects on the formation of smooth perovskite thin films. These organic contaminants make the FTO substrates somewhat hydrophobic, thereby leading to a high contact angle for the polar solvents and a low wettability for the substrates. For spin-coating depositions, these effects result in rough perovskite thin films. Even after careful chemical cleaning, the surfaces of FTO substrates still contain chemisorbed small organic species. UVO or $\mathrm{O}_{2}$ plasma treatment is widely used as a cleaning process ${ }^{22-24}$. We found that UVO treatment can effectively remove the residual organic species and, therefore, significantly reduce the contact angle of the polar solvents (Supplementary Fig. 2). As a result, perovskite thin films with improved smoothness and coverage were obtained. Figure 2a,b shows secondary electron micrographs (SEMs) of $\mathrm{CH}_{3} \mathrm{NH}_{3} \mathrm{PbI}_{3-x} \mathrm{Cl}_{x}$ perovskite thin films grown on FTO substrates with and without UVO treatment, respectively. Based on device performance, the optimal UVO treatment time was found to be $\sim 30 \mathrm{~min}$. It is seen that the $\mathrm{CH}_{3} \mathrm{NH}_{3} \mathrm{PbI}_{3-x} \mathrm{Cl}_{x}$ perovskite thin films deposited on FTO substrates with UVO treatment exhibit larger grains and a lower density of pin holes than the films deposited on FTO substrates without UVO treatment. Because of the improved surface smoothness, the spiro-OMeTAD HTL can be coated smoothly, as shown in Fig. 2c. The cross-sectional SEM image of a planar perovskite-based solar cell grown directly on FTO-coated glass is shown in Fig. 2d, revealing no compact layer, mesoporous layer or porous scaffold supporting layer. For comparison, an SEM image taken from a $\mathrm{CH}_{3} \mathrm{NH}_{3} \mathrm{PbI}_{3-x} \mathrm{Cl}_{x}$ perovskite thin film deposited on a FTO substrate without UVO treatment is shown in Supplementary Fig. 3. The perovskite film is less smooth as compared with the films deposited on UVOtreated FTO substrates.

Lead halide perovskites exhibit extremely high optical absorption and high defect tolerance ${ }^{25,26}$. The spin-coated
$\mathrm{CH}_{3} \mathrm{NH}_{3} \mathrm{PbI}_{3-x} \mathrm{Cl}_{x}$ perovskite thin films were examined by ultraviolet-visible spectroscopy, X-ray diffraction and room temperature photoluminescence (PL). The results shown in Supplementary Fig. 4 indicate that our spin-coated $\mathrm{CH}_{3} \mathrm{NH}_{3} \mathrm{PbI}_{3-x} \mathrm{Cl}_{x}$ perovskite thin films exhibit similar structural and optical properties as reported in literature $3,20,21,27$.

Photovoltaic performance. As described above, the UVO treatment of FTO substrates improves the quality of $\mathrm{CH}_{3} \mathrm{NH}_{3} \mathrm{PbI}_{3-x} \mathrm{Cl}_{x}$ films, and therefore is expected to improve cell performance. Figure 3 a shows the $J-V$ curves of two typical $\mathrm{CH}_{3} \mathrm{NH}_{3} \mathrm{PbI}_{3-x} \mathrm{Cl}_{x}$-based solar cells grown on FTO substrates with (solid red curve) and without (open black curve) UVO treatment. The cell grown on FTO substrate with UVO treatment exhibited a $V_{\mathrm{OC}}$ of $1.02 \mathrm{~V}$, a short-circuit current $\left(J_{\mathrm{SC}}\right)$ of $21.02 \mathrm{~mA} \mathrm{~cm}^{-2}$, a FF of 0.59 and a PCE of $12.72 \%$. However, the cell fabricated with identical conditions but on a FTO substrate without UVO treatment showed a $V_{\text {OC }}$ of $0.96 \mathrm{~V}$, a $J_{\mathrm{SC}}$ of $17.93 \mathrm{~mA} \mathrm{~cm}^{-2}$, a FF of 0.45 and a PCE of $7.67 \%$. Both cells were measured with a reverse voltage scan. Therefore, the observed differences are not caused by measurement variations. The series resistances $\left(R_{\mathrm{S}}\right)$ of the cells grown on FTO substrates with and without UVO treatment are 3.90 and $7.19 \Omega \mathrm{cm}^{2}$, respectively. The shunt resistance $\left(R_{\mathrm{sh}}\right)$ of the cells grown on FTO substrates with and without UVO treatment are 900 and $360 \Omega \mathrm{cm}^{2}$, respectively. It is seen that the UVO treatment of FTO substrates improves the $J_{\mathrm{SC}}, \mathrm{FF}, V_{\mathrm{OC}}$ and PCE, reduces the $R_{\mathrm{S}}$ and increases the $R_{\mathrm{sh}}$. This is consistent with the observation that UVO treatment of FTO substrates improves the smoothness and coverage of $\mathrm{CH}_{3} \mathrm{NH}_{3} \mathrm{PbI}_{3-x} \mathrm{Cl}_{x}$ films. The improved coverage should reduce the amount of direct contact between the FTO and the HTL, which should result in increased $R_{\mathrm{sh}}$ and carrier lifetime, and therefore $V_{\mathrm{OC}}$. Furthermore, UVO treatment has also been widely reported to increase the work functions of metal oxides ${ }^{28-31}$. It is possibly through the reduction of the concentration of oxygen
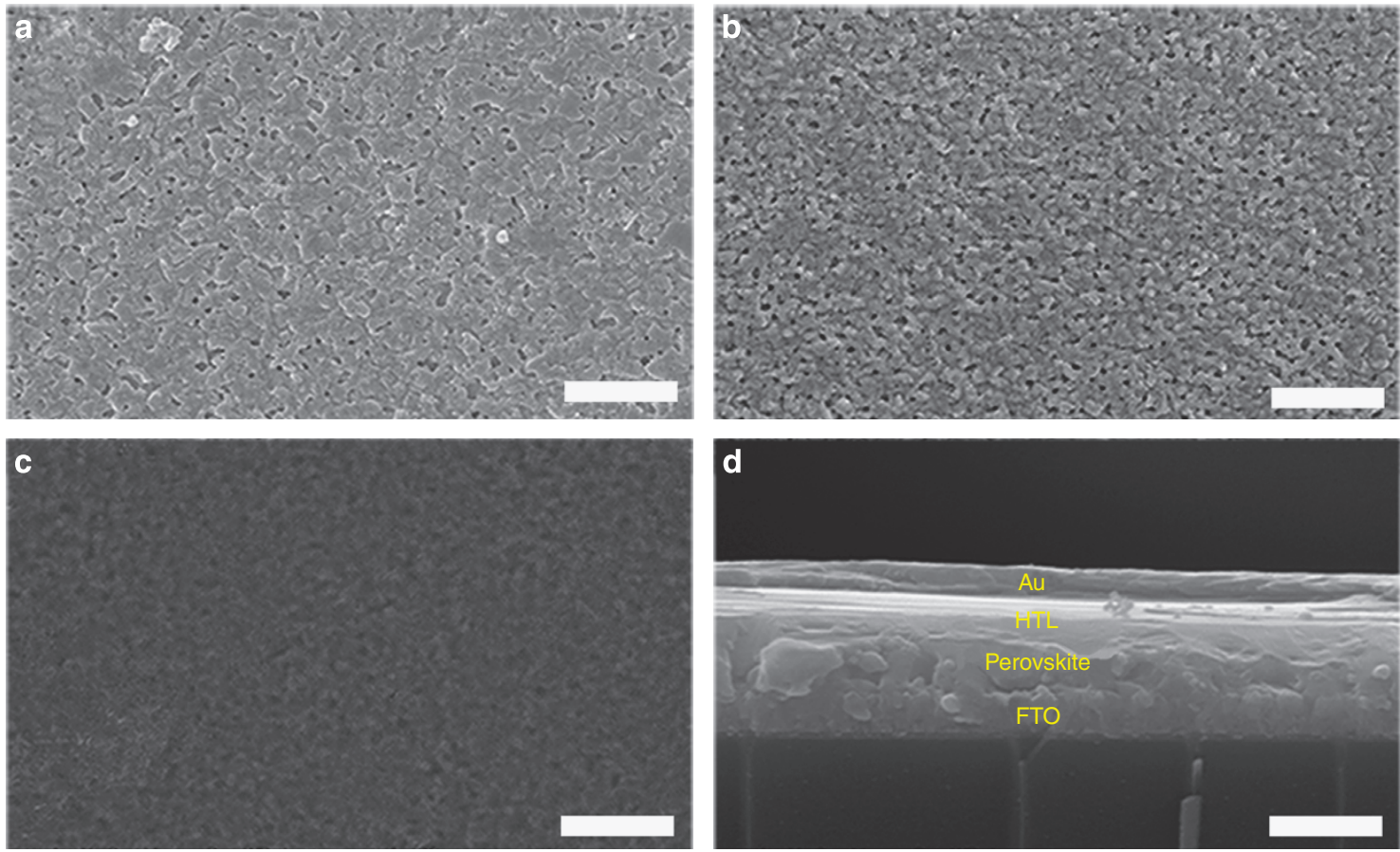

Figure 2 | Film and device morphologies. Top-view SEM images of the $\mathrm{CH}_{3} \mathrm{NH}_{3} \mathrm{Pbl}_{3-x} \mathrm{Cl}_{x}$ films on $\mathrm{FTO}$ (a) with and (b) without UVO treatment. Scale bar, $10 \mu \mathrm{m}$. (c) Top-view SEM image of the HTL on a $\mathrm{CH}_{3} \mathrm{NH}_{3} \mathrm{Pbl}_{3-x} \mathrm{Cl}_{x}$ film deposited on FTO with UVO treatment. Scale bar, $10 \mu \mathrm{m}$. (d) Cross-sectional SEM image of a complete device. Scale bar, $1 \mu \mathrm{m}$. 

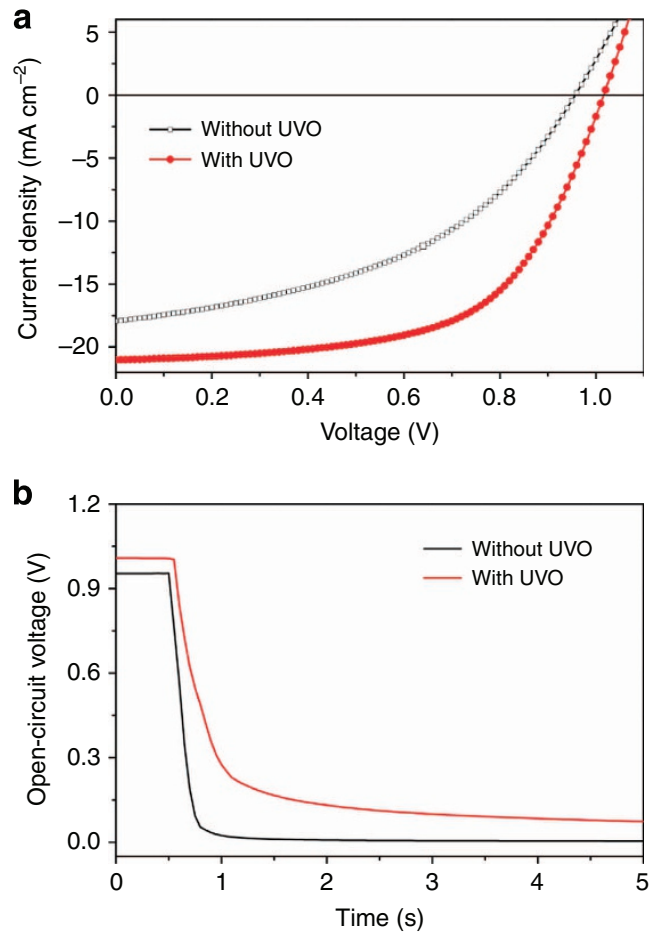

Figure 3 | Effects of UVO treatment. (a) $J-V$ curves and (b) $V_{O C}$ decay curves of two typical $\mathrm{CH}_{3} \mathrm{NH}_{3} \mathrm{Pbl}_{3-x} \mathrm{Cl}_{x}$-based solar cells grown on FTO substrates with and without UVO treatment.

vacancy and therefore a downshift of Fermi level ${ }^{31}$. It has already been confirmed that UVO treatment has an effect on electrical and photovoltaic properties of metal oxides ${ }^{28,29}$. A reduced electron concentration of the FTO surface layer is expected to lower interfacial recombination and improve $V_{\mathrm{OC}}$. These are confirmed by the $V_{\mathrm{OC}}$ decay measurements, which are related to the charge carrier recombination rate and the carrier lifetime ${ }^{32,33}$. The measured $V_{\mathrm{OC}}$ decay curves of two representative perovskite solar cells grown on FTO substrates with and without UVO treatment are shown in Fig. 3b. The cell grown on FTO substrate with UVO treatment exhibited a longer $V_{\mathrm{OC}}$ decay time than the cell grown on FTO substrate without UVO treatment.

The thickness of the light-absorbing layer plays an important role in determining the performance of thin-film solar cells ${ }^{34}$. If the absorber layer is too thin, not enough light will be absorbed, which will lead to low current. If the absorber layer is too thick, the phtotogenerated carriers cannot be collected effectively because they must travel through the absorber layer and reach the carrier collecting layers before they recombine. We have investigated the effects of the $\mathrm{CH}_{3} \mathrm{NH}_{3} \mathrm{PbI}_{3-x} \mathrm{Cl}_{x}$ film thickness on the device performance. The measured $J-V$ curves under reverse voltage scans are shown in Fig. 4. Table 1 shows the photovoltaic parameters of perovskite solar cells with various absorber thicknesses grown on FTO substrates with UVO treatment. It is seen that both the $V_{\mathrm{OC}}$ and $J_{\mathrm{SC}}$ increase as the thickness of the $\mathrm{CH}_{3} \mathrm{NH}_{3} \mathrm{PbI}_{3-x} \mathrm{Cl}_{x}$ film increases. However, the FF first increases then decreases as the thickness of the $\mathrm{CH}_{3} \mathrm{NH}_{3} \mathrm{PbI}_{3-x} \mathrm{Cl}_{x}$ film increases. As a result, the PCE also first increases and then decreases as the thickness of the $\mathrm{CH}_{3} \mathrm{NH}_{3} \mathrm{PbI}_{3-x} \mathrm{Cl}_{x}$ film increases. The optimum thickness of the perovskite $\mathrm{CH}_{3} \mathrm{NH}_{3} \mathrm{PbI}_{3-x} \mathrm{Cl}_{x}$ film is $\sim 500 \mathrm{~nm}$.

It is noted that including $\mathrm{Cl}$ in the precursors is another key for realizing high $V_{\mathrm{OC}} \quad \mathrm{CH}_{3} \mathrm{NH}_{3} \mathrm{PbI}_{3-x} \mathrm{Cl}_{x}$-based solar cells grown directly on FTO substrates without any HBLs. $\mathrm{CH}_{3} \mathrm{NH}_{3} \mathrm{PbI}_{3}$-based solar cells grown directly on FTO substrates without any HBLs have exhibited extremely poor FFs and $V_{\mathrm{OC}}$ 's

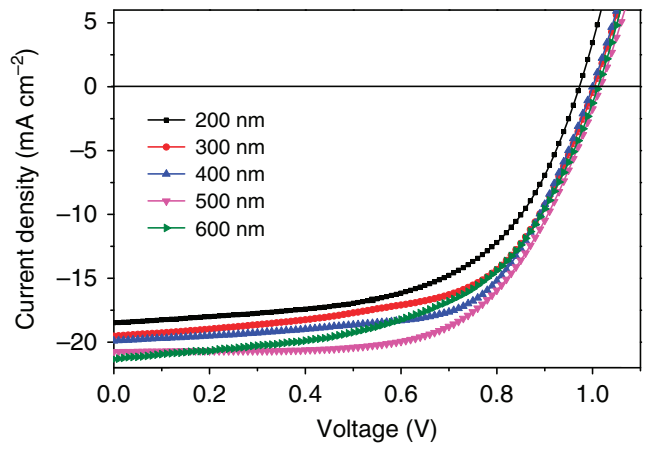

Figure 4 | Photocurrent density-voltage curves. Measured $J-V$ curves of $\mathrm{CH}_{3} \mathrm{NH}_{3} \mathrm{Pbl}_{3-x} \mathrm{Cl}_{x}$-based solar cells with various absorber thicknesses. The thicknesses of the perovskite films were controlled by the spin rate.

(Supplementary Fig. 5). The dark $J-V$ curve indicates a poor rectify behaviour, a common feature for cells with direct contacts between absorbers and electrodes. The poor $V_{\mathrm{OC}}$ is expected because holes generated in $\mathrm{CH}_{3} \mathrm{NH}_{3} \mathrm{PbI}_{3}$ will recombine with electrons from the FTO substrate. X-ray diffraction and SEM (Supplementary Fig. 6) showed that $\mathrm{CH}_{3} \mathrm{NH}_{3} \mathrm{PbI}_{3}$ thin films exhibited similar coverage and crystallinity as $\mathrm{CH}_{3} \mathrm{NH}_{3} \mathrm{PbI}_{3-x} \mathrm{Cl}_{x}$ thin films. The high $V_{\mathrm{OC}}$ 's seen in $\mathrm{CH}_{3} \mathrm{NH}_{3} \mathrm{PbI}_{3-x} \mathrm{Cl}_{x}$-based solar cells should, therefore, not be due to $\mathrm{Cl}$-enhanced film quality. A recent theoretical study has shown that $\mathrm{Cl}$ may segregate to and passivate $\mathrm{TiO}_{2} / \mathrm{CH}_{3} \mathrm{NH}_{3} \mathrm{PbI}_{3-x} \mathrm{Cl}_{x}$ interface, leading to enhanced carrier lifetime ${ }^{35}$. Passivation of interfaces at electron collecting layer and perovskite films has been found to improve the performance of perovskite solar cells ${ }^{36}$. To investigate the charge extraction process in $\mathrm{CH}_{3} \mathrm{NH}_{3} \mathrm{PbI}_{3-x} \mathrm{Cl}_{x}$ and $\mathrm{CH}_{3} \mathrm{NH}_{3} \mathrm{PbI}_{3}$ films, we performed time correlated singlephoton counting luminescence decays for the $\mathrm{CH}_{3} \mathrm{NH}_{3} \mathrm{PbI}_{3-x} \mathrm{Cl}_{x}$ and $\mathrm{CH}_{3} \mathrm{NH}_{3} \mathrm{PbI}_{3}$ (Supplementary Fig. 7). The PL quenching measurements are related to the electron-hole diffusion lengths and lifetimes ${ }^{37,38}$. As shown in Supplementary Fig. 7, the $\mathrm{CH}_{3} \mathrm{NH}_{3} \mathrm{PbI}_{3-x} \mathrm{Cl}_{x}$ film has a longer charge-carrier lifetime than the $\mathrm{CH}_{3} \mathrm{NH}_{3} \mathrm{PbI}_{3}$ film. Therefore, we speculate that the high $V_{\mathrm{OC}}$ 's achieved in $\mathrm{CH}_{3} \mathrm{NH}_{3} \mathrm{PbI}_{3-x} \mathrm{Cl}_{x}$-based solar cells may be due to $\mathrm{Cl}$-facilitated interface passivation. Similar effects have been observed in $\mathrm{HCl}$-treated tin-doped indium oxide substrates used in organic photovoltaic cells ${ }^{39}$. Furthermore, as discussed earlier, UVO treatment to FTO substrates may also help reduce interface recombination. $\mathrm{Cl}$ in precursors has also been found to improve perovskite film quality such as coverage ${ }^{40,41}$. However, we did not observe significant difference on film coverage for $\mathrm{CH}_{3} \mathrm{NH}_{3} \mathrm{PbI}_{3}$ and $\mathrm{CH}_{3} \mathrm{NH}_{3} \mathrm{PbI}_{3-x} \mathrm{Cl}_{x}$ films in our study. We have tried with great efforts to measure $\mathrm{Cl}$ concentration at $\mathrm{FTO} / \mathrm{CH}_{3} \mathrm{NH}_{3} \mathrm{PbI}_{3}$ ${ }_{x} \mathrm{Cl}_{x}$ interfaces, but no noticeable $\mathrm{Cl}$ has been found. We suspect that the amount of $\mathrm{Cl}$ present at $\mathrm{FTO} / \mathrm{CH}_{3} \mathrm{NH}_{3} \mathrm{PbI}_{3-x} \mathrm{Cl}_{x}$ interfaces could be below the detection limit of our instrument. Further investigations are needed to understand the effects of $\mathrm{Cl}$.

Junction properties. The $J-V$ curves of the best-performing $\mathrm{CH}_{3} \mathrm{NH}_{3} \mathrm{PbI}_{3-x} \mathrm{Cl}_{x}$-based solar cell grown directly on a UVOtreated FTO substrate, under illumination and in the dark, are shown in Fig. 5a. This cell has achieved a maximum PCE of $14.14 \%$ with a $V_{\mathrm{OC}}$ of $1.06 \mathrm{~V}$, a $J_{\mathrm{SC}}$ of $19.76 \mathrm{~mA} \mathrm{~cm}^{-2}$ and a FF of 0.67 under the reverse voltage scan with a scan rate of $0.1 \mathrm{~V} \mathrm{~s}^{-1}$. It is well known that perovskite solar cells exhibit hysteresis effect, especially the cells with a planar structure ${ }^{36,42}$. We have observed similar hysteresis behaviours in our perovskite cells grown directly on FTO substrates, as shown in Supplementary Fig. 8 and Supplementary Table 1 . For the same device, the $V_{\mathrm{OC}}, J_{\mathrm{SC}}, \mathrm{FF}$ 
Table 1 | Photovoltaic parameters of the perovskite solar cells.

\begin{tabular}{|c|c|c|c|c|}
\hline Film thickness (nm) & $v_{\text {oc }}(\mathbf{V})$ & $J_{\mathrm{SC}}\left(\mathrm{mA} \mathrm{cm}^{-2}\right)$ & FF & PCE (\%) \\
\hline 200 & 0.98 & 18.49 & 0.57 & 10.36 \\
\hline 300 & 1.01 & 19.52 & 0.59 & 11.66 \\
\hline 400 & 1.01 & 19.90 & 0.63 & 12.58 \\
\hline 500 & 1.02 & 20.76 & 0.63 & 13.26 \\
\hline 600 & 1.02 & 21.33 & 0.55 & 11.87 \\
\hline
\end{tabular}
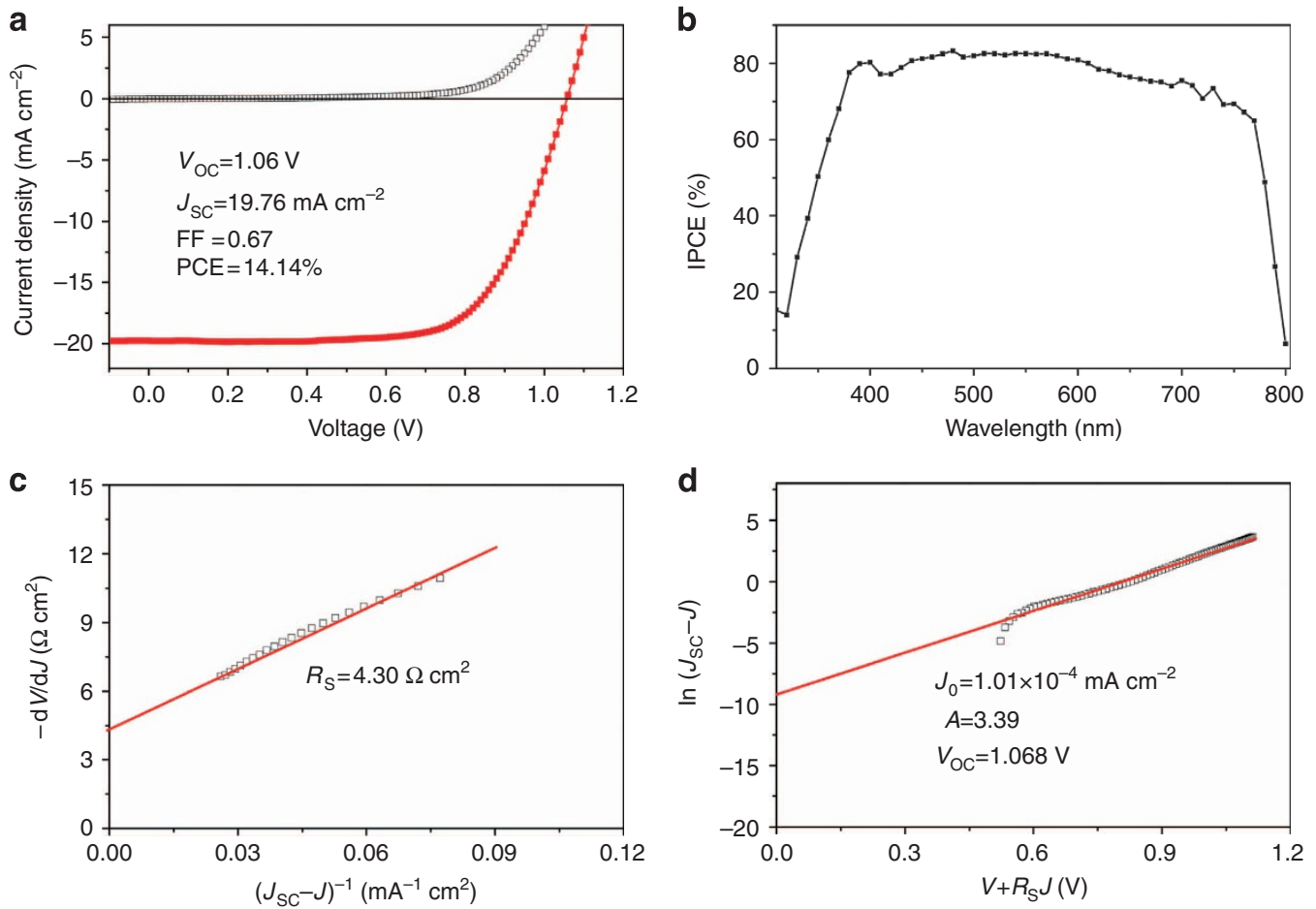

Figure 5 | Photovoltaic and junction performances. (a) $J-V$ curves of the best-performing cell composed of $U V O$-treated $\mathrm{FTO} / 500 \mathrm{~nm} \mathrm{CH}_{3} \mathrm{NH}_{3} \mathrm{Pbl}_{3-x} \mathrm{Cl}_{x} /$ spiro-OMeTAD/Au under AM1.5 simulated irradiation (closed red squares) and in the dark (open black squares). (b) IPCE spectrum of the best-performing cell composed of UVO-treated FTO/500 nm $\mathrm{CH}_{3} \mathrm{NH}_{3} \mathrm{Pbl}_{3-x} \mathrm{Cl}_{x} /$ spiro-OMeTAD/Au. (c) The linear curve of the relationship of $-\mathrm{dV} / \mathrm{d} J$ and $\left(J_{\mathrm{SC}}-J\right.$ ) ${ }^{-1}$. (d) The plot of the relationship of $\ln \left(J_{\mathrm{SC}}-J\right)$ and $V+R_{\mathrm{S}} J$. The junction properties are based on the best-performing cell. The red lines are best linear fits to the data.

and PCE depend on both the voltage scan direction and rate. The $V_{\mathrm{OC}}, J_{\mathrm{SC}}, \mathrm{FF}$ and PCE are $1.04 \mathrm{~V}, 19.78 \mathrm{~mA} \mathrm{~cm}^{-2}, 0.65$ and $13.35 \%$, respectively, when measured under a reverse scan (from $V_{\mathrm{OC}}$ to $0 \mathrm{~V}$ ) with a scan rate of $0.1 \mathrm{~V} \mathrm{~s}^{-1}$, whereas the $V_{\mathrm{OC}}, J_{\mathrm{SC}}$, FF and PCE are $0.96 \mathrm{~V}, 19.97 \mathrm{~mA} \mathrm{~cm}^{-2}, 0.52$ and $10.04 \%$, respectively, when measured under forward scan (from $0 \mathrm{~V}$ to $\left.V_{\text {OC }}\right)$ with the scan rate of $0.1 \mathrm{~V} \mathrm{~s}^{-1}$. Clearly, with the same scan rate, the reverse scan resulted in higher $V_{\mathrm{OC}}, \mathrm{FF}$ and PCE than the forward scan. Furthermore, the higher scan rate resulted in a higher efficiency for the same scan direction. For example, under reverse scan, the $0.1 \mathrm{~V} \mathrm{~s}^{-1}$ scan rate showed a PCE of $13.35 \%$, while the $0.01 \mathrm{~V} \mathrm{~s}^{-1}$ scan rate showed a PCE of $11.23 \%$. Supplementary Fig. 9 and Supplementary Table 2 show the $J-V$ curves of a representative HBL-free cell measured under forward and reverse voltage scans with five cycles. A stable average efficiency of $11.26 \%$ was achieved after the cell measured with five cycles. It has been demonstrated that hysteresis of perovskite solar cells can be reduced or even eliminated by special interface passivation $^{36}$. Therefore, further work is needed to reduce or eliminate the hysteresis in our cells. Figure $5 \mathrm{~b}$ shows the incident photon-to-current conversion efficiency (IPCE) spectrum of this cell. The IPCE spectrum shows efficiencies of $\sim 80 \%$ in the $400-750-\mathrm{nm}$ wavelength range, which is consistent with the ultraviolet-visible absorbance of the perovskite $\mathrm{CH}_{3} \mathrm{NH}_{3} \mathrm{PbI}_{3-x} \mathrm{Cl}_{x}$ film. The dark current density-voltage curve of the solar cell based on the $\mathrm{CH}_{3} \mathrm{NH}_{3} \mathrm{PbI}_{3-x} \mathrm{Cl}_{x}$ film shows good rectification characteristics (Fig. 5a).

Because the $J-V$ curves show good rectification characteristics, the $R_{\mathrm{S}}$ and $V_{\mathrm{OC}}$ of the cell can be calculated according to the diode equation ${ }^{14}$ :

$$
\begin{gathered}
-\mathrm{d} V / \mathrm{d} J=A K_{\mathrm{B}} T\left(J_{\mathrm{SC}}-J\right)^{-1} e^{-1}+R_{\mathrm{S}} \\
\ln \left(J_{\mathrm{SC}}-J\right)=\left(V+R_{\mathrm{S}} \times J\right) e A^{-1} K_{\mathrm{B}}^{-1} T^{-1}+\ln J_{0} \\
V_{\mathrm{OC}} \approx A K_{\mathrm{B}} T e^{-1} \ln \left(J_{\mathrm{SC}} J_{0}^{-1}\right)
\end{gathered}
$$

where $T$ is the absolute temperature, $K_{\mathrm{B}}$ is Boltzmann constant, $A$ is ideality factor and $J_{0}$ is the reverse saturated current density ${ }^{14}$. The $R_{\mathrm{S}}$ and $V_{\mathrm{OC}}$ can be obtained from equations (1) and (3), respectively. Figure $5 \mathrm{c}$ shows a linear relationship between $-\mathrm{d} V /$ $\mathrm{d} J$ and $\left(J_{\mathrm{SC}}-J\right)^{-1}$. The value of $R_{\mathrm{S}}$ is equal to the intercept on the $y$ axis. The $R_{\mathrm{S}}$ of the device without a conventional HBL is $4.30 \Omega \mathrm{cm}^{2}$. 
According to equation (2), $J_{0}$ is equal to the $y$ intercept of the line in Fig. $5 \mathrm{~d}$. The values of $J_{0}$ and $A$ are $1.01 \times 10^{-4} \mathrm{~mA} \mathrm{~cm}^{-2}$ and 3.39, respectively. According to equation (3), the calculated value of the $V_{\mathrm{OC}}$ is $1.068 \mathrm{~V}$; this calculated value is very close to the value obtained from the $J-V$ measurement.

Reproducibility and stability. To check the reproducibility of the performance of the simple heterojunction perovskite solar cells, we fabricated and measured 56 separate devices. Supplementary Figure 10 shows the histograms of the photovoltaic parameters. The average values of $V_{\mathrm{OC}}$ and $J_{\mathrm{SC}}$ are $1.00 \mathrm{~V}$ and $20.08 \mathrm{~mA} \mathrm{~cm}^{-2}$, respectively. Most of the devices show a PCE higher than $11 \%$, revealing a high reproducibility. Supplementary Figure 11 shows the results of long-term stability tests of the devices without HBLs. The test was done by measuring the $J-V$ curves of the devices after stored for a certain period of time. The tested devices were not encapsulated and were stored in atmosphere with humidity of $20 \%$ and at room temperature without light illumination. The values of FF and PCE first increased and then decreased. The values of $V_{\mathrm{OC}}$ remained unchanged for a long period. The initial increase in cell performance may be attributed to oxygen-induced doping of spiroOMeTAD, which has been reported in literature $e^{43,44}$. The PCE of the non-encapsulated perovskite solar cell was $>70 \%$ of its initial value after $500 \mathrm{~h}$ (Supplementary Fig. 11).

\section{Discussion}

The highest $V_{\mathrm{OC}}$ achieved with our $\mathrm{CH}_{3} \mathrm{NH}_{3} \mathrm{PbI}_{3-x} \mathrm{Cl}_{x}$-based perovskite solar cells grown directly on FTO substrates without any HBLs is $1.06 \mathrm{~V}$. As the perovskite layers were deposited by the one-step spin-coat process, remnant $\mathrm{PbI}_{2}$ layers acting as $\mathrm{HBLs}$ can be excluded. Such a high $V_{\text {OC }}$ is unexpected for a solar cell grown directly on a conductive electrode. As discussed above, including $\mathrm{Cl}$ and applying $\mathrm{UVO}$ treatment to FTO substrates are the key for achieving the high $V_{\mathrm{OC}}$ 's. To test if including a $\mathrm{TiO}_{2}$ $\mathrm{HBL}$ would further significantly improve the $V_{\mathrm{OC}}$, we have incorporated a thin layer of $\mathrm{TiO}_{2}$ on FTO substrates. Figure 6 shows the $J-V$ curves (reverse scan) of the best-performing $\mathrm{CH}_{3} \mathrm{NH}_{3} \mathrm{PbI}_{3-x} \mathrm{Cl}_{x}$-based solar cell with a 60 -nm-thick undoped $\mathrm{TiO}_{2}$ layer. The obtained $V_{\mathrm{OC}}$ is $\sim 1.06 \mathrm{~V}$. It is seen that the cell efficiency has been improved. Surprisingly, however, there was no improvement on the $V_{\mathrm{OC}}$. The efficiency improvement was due to the enhancements of $\mathrm{FF}$ and $J_{\mathrm{SC}}$. As speculated, $\mathrm{Cl}$ may diffuse to and passivate $\mathrm{FTO} / \mathrm{CH}_{3} \mathrm{NH}_{3} \mathrm{PbI}_{3-x} \mathrm{Cl}_{x}$ interfaces, and lead to the observed high $V_{\mathrm{OC}}$ 's for $\mathrm{CH}_{3} \mathrm{NH}_{3} \mathrm{PbI}_{3-x} \mathrm{Cl}_{x}$-based perovskite solar cells grown directly on FTO substrates without HBLs. The passivation seems to be as effective as the $\mathrm{TiO}_{2} \mathrm{HBL}$. Therefore, our results suggest that $\mathrm{TiO}_{2}$ may not be the ultimate HBL material for achieving high-efficiency lead halide perovskite solar

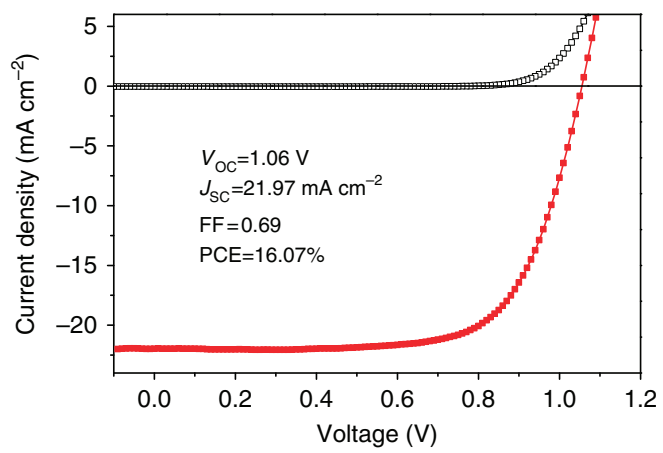

Figure 6 | Cell performance. $J-V$ curves of a perovskite-based solar cell composed of $\mathrm{FTO} / 60 \mathrm{~nm} \mathrm{TiO} 2 / 500 \mathrm{~nm} \mathrm{CH}_{3} \mathrm{NH}_{3} \mathrm{Pbl}_{3-x} \mathrm{Cl}_{x} /$ spiro-OMeTAD/ Au. cells. We anticipate that other oxide-based HBLs may also be able to produce high-efficiency lead halide perovskite solar cells and should be explored. While this paper was under review, a relevant paper was published ${ }^{45}$. It was suggested that the remnant $\mathrm{PbI}_{2}$ layer, an unavoidable residual layer for the two-step process, at $\mathrm{FTO} / \mathrm{CH}_{3} \mathrm{NH}_{3} \mathrm{PbI}_{3}$ interface could act as a HBL.

In summary, we have demonstrated high $V_{\mathrm{OC}}$ efficient planar $\mathrm{CH}_{3} \mathrm{NH}_{3} \mathrm{PbI}_{3-x} \mathrm{Cl}_{x}$-based thin-film solar cells grown directly on FTO glass substrates without any HBLs. The best-performing perovskite solar cell has achieved a PCE of $14.14 \%$ and a high $V_{\mathrm{OC}}$ of $1.06 \mathrm{~V}$. This $V_{\mathrm{OC}}$ is as high as our best reference cell using a $\mathrm{TiO}_{2}$ $\mathrm{HBL}\left(\mathrm{PCE}=16.07 \%, V_{\mathrm{OC}}=1.06 \mathrm{~V}\right)$. We have shown that UVO treatment of FTO substrates and including $\mathrm{Cl}$ in precursors are two key factors that ensure the high $V_{\text {OC }}$ for lead halide perovskite solar cells grown directly on FTO substrates without HBLs. While the actual mechanism deserves more careful study, our results strongly suggest that $\mathrm{TiO}_{2}$ may not be the ultimate HBLs for achieving high-efficiency lead halide perovskite solar cells. Our results also provide insights on how to improve the performance of lead halide perovskite solar cells using other metal oxides.

\section{Methods}

Solar cell fabrication. The perovskite $\mathrm{CH}_{3} \mathrm{NH}_{3} \mathrm{PbI}_{3}$ and $\mathrm{CH}_{3} \mathrm{NH}_{3} \mathrm{PbI}_{3-x} \mathrm{Cl}_{x}$ films were synthesized by the one-step process as reported in literature $e^{6,46,47}$. First, $19.8 \mathrm{ml}(0.15 \mathrm{~mol})$ hydroiodic acid (Sigma-Aldrich, $57 \mathrm{wt} . \%$ in water, $99.99 \%)$ and $18.7 \mathrm{ml}(0.15 \mathrm{~mol})$ methylamine (Sigma-Aldrich, $33 \mathrm{wt} . \%$ in absolute ethanol) at a 1:1 equimolar ratio were stirred in an ice bath for $2 \mathrm{~h}$. The precipitate was collected by evaporating at $50^{\circ} \mathrm{C}$ for $2 \mathrm{~h}$. Finally, a white powder was received by washing with diethyl ether and ethanol three times and then drying at $100{ }^{\circ} \mathrm{C}$ in a vacuum oven for $24 \mathrm{~h}$. A precursor solution of $\mathrm{CH}_{3} \mathrm{NH}_{3} \mathrm{PbI}_{3-x} \mathrm{Cl}_{x}$ was composed of $\mathrm{CH}_{3} \mathrm{NH}_{3} \mathrm{I}$ and $\mathrm{PbCl}_{2}$ (Aladdin reagent, 99.99\%) with a molar ratio of 3:1. The precursor solution of $\mathrm{CH}_{3} \mathrm{NH}_{3} \mathrm{PbI}_{3}$ was composed of $\mathrm{CH}_{3} \mathrm{NH}_{3} \mathrm{I}$ and $\mathrm{PbI}_{2}$ (Aladdin reagent, $99.99 \%$ ) with a molar ratio of $1: 1$. The solvent of the two precursor solutions was anhydrous dimethylformamide (Sinopharm Chemical Reagent Co., Ltd). The solutions were stirred at room temperature for $24 \mathrm{~h}$. $\mathrm{TiO}_{2}$ film coated on FTO substrate was prepared by a spin-coating method and was sintered at $500{ }^{\circ} \mathrm{C}$ for $30 \mathrm{~min}$ (refs 48,49). The perovskite $\mathrm{CH}_{3} \mathrm{NH}_{3} \mathrm{PbI}_{3}$ and $\mathrm{CH}_{3} \mathrm{NH}_{3} \mathrm{PbI}_{3-x} \mathrm{Cl}_{x}$ films coated on FTO glasses (Asahi Glass, $14 \mathrm{Ohm}$ per square) were prepared by a spincoating method. The thicknesses of the $\mathrm{CH}_{3} \mathrm{NH}_{3} \mathrm{PbI}_{3-x} \mathrm{Cl}_{x}$ films were controlled by the spin rate with a same solution. The FTO glasses were treated with UVO for $30 \mathrm{~min}$. Before spin coating, the precursor solutions and the substrates were preheated at $60^{\circ} \mathrm{C}$ for $15 \mathrm{~min}$. The perovskite $\mathrm{CH}_{3} \mathrm{NH}_{3} \mathrm{PbI}_{3-x} \mathrm{Cl}_{x}$ and $\mathrm{CH}_{3} \mathrm{NH}_{3} \mathrm{PbI}_{3}$ films were heated at $100^{\circ} \mathrm{C}$ in a vacuum oven for 45 and $15 \mathrm{~min}$, respectively. The hole-transporting material was composed of $68 \mathrm{mM}$ spiro-OMeTAD (Shenzhen Feiming Science and Technology Co., Ltd, 99.0\%), $26 \mathrm{mM} \mathrm{Li-TFSI} \mathrm{(Aladdin}$ reagent) and $55 \mathrm{mM}$ TBP (Aladdin reagent). The solvent was a mixed solution of acetonitrile and chlorobenzene with a volume ratio of 1:10. It was stirred at room temperature for $24 \mathrm{~h}$ and then was used to coat the perovskite films by a spincoating method at a speed of 2,000 r.p.m. for 30 s. Device fabrication was completed by deposition of a thin gold electrode on the HTL. The active areas of the devices were controlled by a shadow mask in the thermal evaporator.

Characterization. The morphologies of perovskite solar cells were observed by a high-resolution field emission SEM (JSM 6700F). The absorption and transmission spectra of the perovskite $\mathrm{CH}_{3} \mathrm{NH}_{3} \mathrm{PbI}_{3-x} \mathrm{Cl}_{x}$ film on FTO was measured by an ultraviolet-visible spectrophotometer (CARY5000, Varian, Australia) in the 400-800$\mathrm{nm}$ wavelength range at room temperature. Hall measurements were conducted via a LakeShore 7704 Hall Measurement System. PL spectrum was obtained with a 532$\mathrm{nm}$ laser, as the excitation source, pulsed at a frequency of $9.743 \mathrm{MHz}$. The perovskite solar cells were stored in ambient air for a short period of time and then measured under a $100 \mathrm{~mW} \mathrm{~cm}^{-2}$ (AM1.5 simulated irradiation) illumination with a standard ABET Sun 2000 Solar Simulator. The light intensity was calibrated by a standard silicon solar cell. The cell size was $2 \mathrm{~cm} \times 2 \mathrm{~cm}$. The active area was $0.09 \mathrm{~cm}^{2}$, which was defined by the area of the Au electrode. The $J-V$ characteristics were measured by a CHI660D electrochemical workstation (ShangHai, China). The IPCE spectrum was measured by a Quantum Efficiency/IPCE system (PV Measurements Inc.) in the $320-800-n m$ wavelength range at room temperature. All the efficiencies were taken from the initial measurement, except for the test of the stability.

\section{References}

1. Kojima, A., Teshima, K., Shirai, Y. \& Miyasaka, T. Organometal halide perovskites as visible-light sensitizers for photovoltaic cells. J. Am. Chem. Soc. 131, 6050-6051 (2009). 
2. Kim, H.-S. et al. Lead iodide perovskite sensitized all-solid-state submicron thin film mesoscopic solar cell with efficiency exceeding 9\%. Sci. Rep. 2, 591 (2012).

3. Lee, M. M., Teuscher, J., Miyasaka, T., Murakami, T. N. \& Snaith, H. J. Efficient hybrid solar cells based on meso-superstructured organometal halide perovskites. Science 338, 643-647 (2012).

4. Liu, M. Z., Johnston, M. B. \& Snaith, H. J. Efficient planar heterojunction perovskite solar cells by vapour deposition. Nature 501, 395-398 (2013).

5. Burschka, J. et al. Sequential deposition as a route to high-performance perovskite-sensitized solar cells. Nature 499, 316-319 (2013).

6. Zhou, H. P. et al. Interface engineering of highly efficient perovskite solar cells. Science 345, 542-546 (2014).

7. Jeon, N. J. et al. Compositional engineering of perovskite materials for highperformance solar cells. Nature 517, 476-480 (2015)

8. National Renewable Energy Laboratory. www.nrel.gov/ncpv/images/ efficiency_chart.jpg(2015).

9. Shao, Y. C., Xiao, Z. G., Bi, C., Yuan, Y. B. \& Huang, J. S. Origin and elimination of photocurrent hysteresis by fullerene passivation in $\mathrm{CH}_{3} \mathrm{NH}_{3} \mathrm{PbI}_{3}$ planar heterojunction solar cells. Nat. Commun. 5, 5784 (2014).

10. Bi, D. Q., Yang, L., Boschloo, G., Hagfeldt, A. \& Johansson, E. M. J. Effect of different hole transport materials on recombination in $\mathrm{CH}_{3} \mathrm{NH}_{3} \mathrm{PbI}_{3}$ perovskitesensitized mesoscopic solar cells. J. Phys. Chem. Lett. 4, 1532-1536 (2013).

11. Liu, D. Y. \& Kelly, T. L. Perovskite solar cells with a planar heterojunction structure prepared using room-temperature solution processing techniques. Nat. Photon. 8, 133-138 (2013).

12. Mei, A. et al. A hole-conductor-free, fully printable mesoscopic perovskite solar cell with high stability. Science 345, 295-298 (2014).

13. Ku, Z. L., Rong, Y. G., Xu, M., Liu, T. F. \& Han, H. W. Full printable processed mesoscopic $\mathrm{CH}_{3} \mathrm{NH}_{3} \mathrm{PbI}_{3} / \mathrm{TiO}_{2}$ heterojunction solar cells with carbon counter electrode. Sci. Rep. 3, 3132 (2013).

14. Shi, J. J. et al. Hole-conductor-free perovskite organic lead iodide heterojunction thin-film solar cells: high efficiency and junction property. Appl. Phys. Lett. 104, 063901 (2014).

15. Cao, D. H. et al. Remnant $\mathrm{PbI}_{2}$, An unforeseen necessity in high-efficiency hybrid perovskite-based solar cells. APL Mater. 2, 091101 (2014).

16. Seo, J. et al. Benefits of very thin PCBM and LiF layers for solution-processed p-i-n perovskite solar cells. Energy Environ. Sci. 7, 2642-2646 (2014).

17. Edri, E. et al. Why lead methylammonium tri-iodide perovskite-based solar cells require a mesoporous electron transporting scaffold (but not necessarily a hole conductor). Nano Lett. 14, 1000-1004 (2014).

18. Edri, E. et al. Elucidating the charge carrier separation and working mechanism of $\mathrm{CH}_{3} \mathrm{NH}_{3} \mathrm{PbI}_{3-\mathrm{x}} \mathrm{Cl}_{\mathrm{x}}$ perovskite solar cells. Nat. Commun. 5, 3461 (2014).

19. Eperon, G. E., Burlakov, V. M., Docampo, P., Goriely, A. \& Snaith, H. J. Morphological control for high performance, solution-processed planar heterojunction perovskite solar cells. Adv. Funct. Mater. 24, 151-157 (2014).

20. Dualeh, A. et al. Effect of annealing temperature on film morphology of organic-inorganic hybrid pervoskite solid-state solar cells. Adv. Funct. Mater. 24, 3250-3258 (2014).

21. Conings, B. et al. Perovskite-based hybrid solar cells exceeding $10 \%$ efficiency with high reproducibility using a thin film sandwich approach. Adv. Mater. 26, 2041-2046 (2014).

22. Small, C. E. et al. High-efficiency inverted dithienogermole-thienopyrrolodione-based polymer solar cells. Nat. Photon. 6, 115-120 (2011).

23. $\mathrm{Hu}, \mathrm{T}$. et al. Effect of UV-ozone treatment on ITO and post-annealing on the performance of organic solar cells. Synth. Met. 159, 754-756 (2009).

24. Cheng, F. et al. Enhancing the performance of P3HT:ICBA based polymer solar cells using $\mathrm{LiF}$ as electron collecting buffer layer and UV-ozone treated $\mathrm{MoO}_{3}$ as hole collecting buffer layer. Sol. Energy Mater. Sol. Cells 110, 63-68 (2013).

25. Yin, W. J., Shi, T. T. \& Yan, Y. F. Unique properties of halide perovskites as possible origins of the superior solar cell performance. Adv. Mater. 26, 4653-4658 (2014)

26. Yin, W. J., Shi, T. T. \& Yan, Y. F. Unusual defect physics in $\mathrm{CH}_{3} \mathrm{NH}_{3} \mathrm{PbI}_{3}$ perovskite solar cell absorber. Appl. Phys. Lett. 104, 063903 (2014).

27. Liang, P. W. et al. Additive enhanced crystallization of solution-processed perovskite for highly efficient planar-heterojunction solar cells. Adv. Mater. 26, 3748-3754 (2014).

28. Kim, S. Y., Lee, J.-L., Kim, K.-B. \& Tak, Y.-H. Effect of ultraviolet-ozone treatment of indium-tin-oxide on electrical properties of organic light emitting diodes. J. Appl. Phys. 95, 2560 (2004).

29. Hains, A. W., Liu, J., Martinson, A. B. F., Irwin, M. D. \& Marks, T. J. Anode interfacial tuning via electron-blocking/hole-transport layers and indium tin oxide surface treatment in bulk-heterojunction organic photovoltaic cells. Adv. Funct. Mater. 20, 595-606 (2010).

30. Sugiyama, K., Ishii, H., Ouchi, Y. \& Seki, K. Dependence of indium-tin-oxide work function on surface cleaning method as studied by ultraviolet and x-ray photoemission spectroscopies. J. Appl. Phys. 87, 295 (2000).
31. Helander, M. G., Greiner, M. T., Wang, Z. B., Tang, W. M. \& Lu, Z. H. Work function of fluorine doped tin oxide. J. Vac. Sci. Technol. A 29, 011019 (2011).

32. Krishnamoorthy, T. et al. A swivel-cruciform thiophene based holetransporting material for efficient perovskite solar cells. J. Mater. Chem. A 2, 6305-6309 (2014).

33. Tao, H., Fang, G. J., Ke, W. J., Zeng, W. \& Wang, J. In-situ synthesis of $\mathrm{TiO}_{2}$ network nanoporous structure on Ti wire substrate and its application in fiber dye sensitized solar cells. J. Power Sources 245, 59-65 (2014).

34. Liu, D. Y., Gangishetty, M. K. \& Kelly, T. L. Effect of $\mathrm{CH}_{3} \mathrm{NH}_{3} \mathrm{PbI}_{3}$ thickness on device efficiency in planar heterojunction perovskite solar cells. J. Mater. Chem. A 2, 19873-19881 (2014).

35. Mosconi, E., Ronca, E. \& De Angelis, F. First-principles investigation of the $\mathrm{TiO}_{2}$ /organohalide perovskites interface: the role of interfacial chlorine. J. Phys. Chem. Lett. 5, 2619-2625 (2014).

36. Wojciechowski, K. et al. Heterojunction modification for highly efficient organic-inorganic perovskite solar cells. ACS Nano 8, 12701-12709 (2014).

37. Stranks, S. D. et al. Electron-hole diffusion lengths exceeding 1 micrometer in an organometal trihalide perovskite absorber. Science 342, 341-344 (2013).

38. Roiati, V. et al. Investigating charge dynamics in halide perovskite-sensitized mesostructured solar cells. Energy Environ. Sci. 7, 1889-1894 (2014).

39. Irwin, M. D. et al. Consequences of anode interfacial layer deletion. HCl-treated ITO in P3HT:PCBM-based bulk-heterojunction organic photovoltaic devices. Langmuir 26, 2584-2591 (2010).

40. Tidhar, Y. et al. Crystallization of methyl ammonium lead halide perovskites: implications for photovoltaic applications. J. Am. Chem. Soc. 136, 13249-13256 (2014).

41. Williams, S. T. et al. Role of chloride in the morphological evolution of organo-lead halide perovskite thin films. ACS Nano 8, 10640-10654 (2014).

42. Snaith, H. J. et al. Anomalous hysteresis in perovskite solar cells. J. Phys. Chem Lett. 5, 1511-1515 (2014).

43. Cappel, U. B., Daeneke, T. \& Bach, U. Oxygen-induced doping of spiroMeOTAD in solid-state dye-sensitized solar cells and its impact on device performance. Nano Lett. 12, 4925-4931 (2012).

44. Docampo, P. \& Snaith, H. J. Obviating the requirement for oxygen in $\mathrm{SnO}_{2}$ based solid-state dye-sensitized solar cells. Nanotechnology 22, 225403 (2011)

45. Liu, D. L., Yang, J. L. \& Kelly, T. L. Compact layer free perovskite solar cells with $13.5 \%$ efficiency. J. Am. Chem. Soc. 136, 17116-17122 (2014).

46. Docampo, P., Ball, J. M., Darwich, M., Eperon, G. E. \& Snaith, H. J. Efficient organometal trihalide perovskite planar-heterojunction solar cells on flexible polymer substrates. Nat. Commun. 4, 2761 (2013).

47. Sun, S. Y. et al. The origin of high efficiency in low-temperature solutionprocessable bilayer organometal halide hybrid solar cells. Energy Environ. Sci. 7, 399-407 (2014).

48. Ke, W. J. et al. Perovskite solar cell with an efficient $\mathrm{TiO}_{2}$ compact film. ACS Appl. Mater. Interfaces 6, 15959-15965 (2014).

49. Ke, W. J. et al. In situ synthesis of NiS nanowall networks on $\mathrm{Ni}$ foam as a TCO-free counter electrode for dye-sensitized solar cells. ACS Appl. Mater. Interfaces 6, 5525-5530 (2014).

\section{Acknowledgements}

This work was supported by the National High Technology Research and Development Program (2015AA050601), the National Basic Research Program (no. 2011CB933300) of China, the National Natural Science Foundation of China (61376013, 91433203, J1210061), the Research Program of Wuhan Science and Technology Bureau (2013010501010141) and the Fundamental Research Funds for the Central Universities (2014202020207).

\section{Author contributions}

W.K. prepared the samples and carried out the initial experiments. G.F. designed the experiments and gave supervision. Q.L., H.T. and J.W. characterized the perovskite films. J.W.W., P.Q. and H.L. analysed the data. L.X., G.Y. and M.Q. carried out the studies on device hysteresis. X.Z and Y.Y gave guidance. All authors discussed the results and contributed to the writing of the paper.

\section{Additional information}

Supplementary Information accompanies this paper at http://www.nature.com/ naturecommunications

Competing financial interests: The authors declare no competing financial interests.

Reprints and permission information is available online at http://npg.nature.com/ reprintsandpermissions/

How to cite this article: Ke W. et al. Efficient hole-blocking layer-free planar halide perovskite thin-film solar cells. Nat. Commun. 6:6700 doi: 10.1038/ncomms7700 (2015). 